\title{
THE DEVELOPMENT OF THE CONDUCTING SYSTEM IN THE HEART OF SHEEP
}

\author{
BY \\ E. J. FIELD* \\ From the Department of Anatomy, University of Bristol. \\ Received April 11, 1949
}

The views that have been put forward with regard to the development of the conducting system fall into two main categories as follows.

(1) Persistence of original atrioventricular (A-V) canal tissue (Mall, 1912; Koch, 1922).

(2) New formation.

(a) In situ-A-V canal and ventricle (Wahlin, 1935; Sanabria, 1936).

(b) From sinus musculature-with secondary migration distally (Retzer, 1908).

(c) From A-V canal with secondary migration distally (Shaner, 1929; Walls, 1947).

(d) From ventricle with secondary migration proximally (Stiénon, 1925; Ohmori, 1928).

Tandler (1913), though inclined to agree with Retzer (1908) that the bundle was essentially a new formation, maintained that it was derived from the original A-V canal musculature. He pointed out, however, that on account of its special structure and development it should be regarded as a specific entity.

Wahlin (1935) has emphasized that the various suggestions as to the origin of the conducting system are not necessarily mutually exclusive. He himself looks upon the A-V node as " . . . ein Rest des Canalis auricularis . .. a aber auch, wie die übrigen Abschnitte des atrioventrikulären Reizleitungssystems, als eine Neuerwerb wegen seiner ganz speziellen Differenzierung."

All the above authors regard the conducting system as being formed in continuity. Recently, however, Calcagno $(1941 a, b)$ has claimed that the A-V node and bundle develop independently in the bovine embryo and only become joined secondarily.

Side by side with these ontogenetic investigations certain workers have sought to establish the origin and significance of the system on phylogenetic grounds. Thus, Benninghoff (1923) looks upon it as the remnant of an originally extensive system of " Konturfasern " around which a condensed myocardium has been laid down. Davies (1942) adopting a more teleological standpoint, sees the system not as a remnant, but as a neomorphic development specially evolved in birds and mammals to meet the need for rapid dissemination' of the cardiac impulse. In support of this view he adduces the claim made by several workers that the A-V bundle comes into existence before muscular continuity between atria and ventricles has been dissolved. In recent years, however, the whole conception of the conducting system, both as regards structure and function, has been strongly challenged by Glomset and his co-workers (1940-48) in a series of critical and provocative papers. In view of Glomset's criticisms and because preliminary investigation of the adult system showed that at least one important feature - the nervous component of the bundle-had received inadequate attention, the present investigation was undertaken to determine what help an ontogenetic study might afford in evaluating the significance of the system.

\footnotetext{
* Holding a British Medical Association Research Scholarship, 1948-9.
} 


\section{MATERIAL AND METHODS}

The animal studied throughout has been the sheep. The 18-20 day specimens reported on are in the collection of Professors W. J. Hamilton and J. D. Boyd, to whom the author is indebted for their loan. Several of the larger "timed" hearts were obtained through the kindness of the late Sir Joseph Barcroft, but the majority of specimens was collected over the course of the last three seasons at various abattoirs. Smaller embryos were sectioned in toto at 5-8 $\mu$, while from the larger ones selected blocks of tissue were examined. The plane of section was usually coronal, but where duplicate material was available sagittal sections were sometimes made. Staining was carried out by Heidenhain's iron hæmatoxylin, most often without counterstain. The crucial step of differentiation was always carried out by the writer himself and it was found that in this way more instructive and consistent preparations were obtained than by the use of the bulk impregnation method of Blair and Davies (1935). At intervals in a series, slides were stained by Best's carmine method for glycogen and by Bauer's method (using, however, sodium para-periodate as oxidizing agent instead of chromic acid). Some of the older specimens were stained by van Gieson and by Masson stains.

The material comprised (a) complete serial sections through 30 embryos between the 4-mm. and 22.5-mm. stages, including embryos aged 18, 19, 20 (two specimens), 23, and 26 days; (b) complete serial sections through the hearts of 21 embryos between the 24- and 100-mm. stages, and (c) runs of serial sections from blocks of tissue from 21 specimens between $115 \mathrm{~mm}$. and birth $(580 \mathrm{~mm}$.), including fotuses aged 69 and 110 days (two specimens).

\section{OBSERVATIONS}

4-4.5-mm. stage. The cells in the posterior wall of the A-V canal in these specimens are orientated transversely so as to encircle the canal (Fig. 1). They are more open in appearance, though this may result from their direction rather than from true structural difference. This circular arrangement of cells at the A-V ostium is reminiscent of the similar arrangement described in this region in adult lower vertebrate hearts (v. Skramlik, 1921; Benninghoff, 1923). Sanabria (1936) described fine vacuoles within the cytoplasm of the cells of the posterior wall of the A-V canal, and their nuclei as more deeply staining, but such distinctions are not at all marked in the present material; for at this stage all the cells of the heart wall are vesicular in character, and if one were not looking deliberately for the first signs of specialization, there would be little to draw one's attention to the posterior wall of the A-V canal other than the orientation of the cells.

$7 \cdot 5-11-\mathrm{mm}$. stage. The earliest specialization of the myocardium is visible in these specimens. Along the inferior aspect of the dorsal endocardial cushion the cells are clearer and rather more vesicular than in the remaining myocardium (Fig. 2). The nuclei are deeply stained and often crenated. In the $8-m m$. bovine embryo, Wahlin (1935) also noted this shrunken and pyknotic appearance of many nuclei of the primitive bundle. Traced posteriorly the cells of the "bundle" become continuous with those of the posterior wall of the A-V canal behind the posterior endocardial cushion. This is a region in which active cellular proliferation has been described by some authors. Thus, Shaner (1929) found, in the calf, that the " A-V conduction apparatus begins with the laying down of the A-V node." This node he described as making its appearance at the 9-mm. stage and becoming unmistakable as a projecting blob of frothy protoplasm by the $13-15-\mathrm{mm}$. stage. He implied, though he did not explicitly state, that it was a migration of cells from this node which gave rise to the A-V bundle (p. 86). Walls (1947)-on the basis of two transversely sectioned heartsfollows Shaner's description and records an active growth process taking place from the node. Neither of these authors, however, offers convincing evidence-e.g. mitotic or amitotic figures-for such activity. The same criticism may be levelled at Retzer (1908)and Ohmori (1928), both of whom regard the bundle as reaching its definitive location by an active growth process. Sanabria (1936) speaks of "une prolifération-peut être aussi . . . une migration" as taking place behind the posterior endocardial cushion. Stiénon (1925) maintains that the bundle is formed by an upward 
migration of cells from the spongy musculature that crowns the interventricular septum. But here again satisfactory evidence for an active migration is not apparent.

The sagittal section (Fig. 2) shows that it is along the under surface of the posterior endocardial cushion and not in the posterior wall of the A-V canal that earliest differentiation is found. The cells in the former situation were somewhat richer in glycogen than is the general myocardium. There is no evidence whatsoever that the bundle arises by active growth from a distant focus either in the $A-V$ canal or in the ventricle. Rather the appearances seen in sagittal section taken together with the coronal picture suggest a local retention of more primitive features in a region where there is relative immobility - a suggestion first put forward by Keith and Flack (1906). The manner in

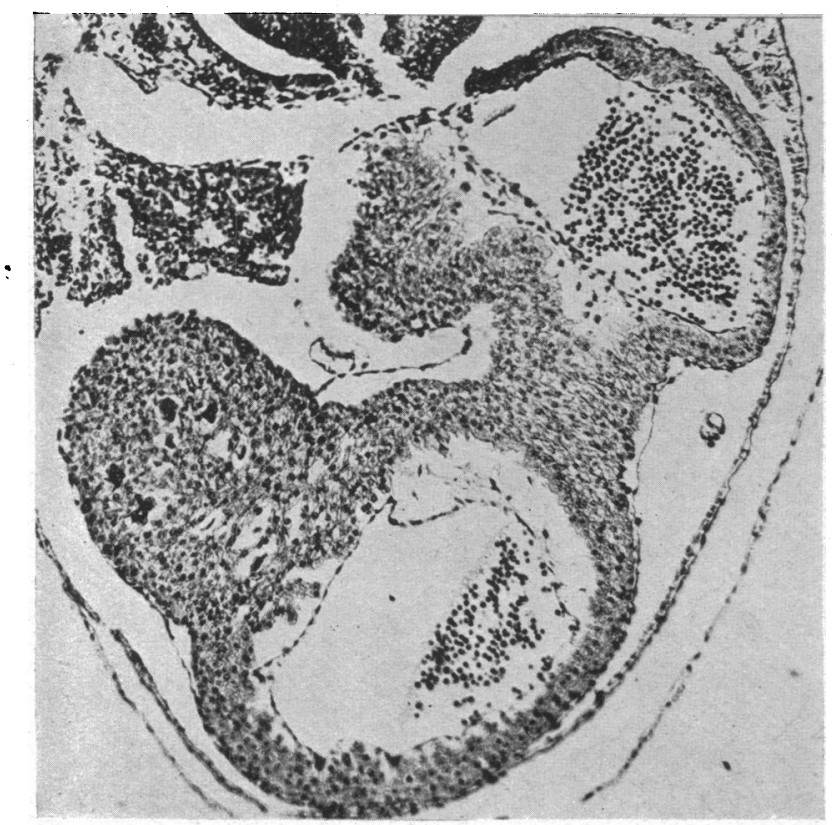

FIG. 1.-Coronal section through heart of 4-mm. (18 day) sheep embryo (B27). The section passes through the posterior wall of the A-V canal where the cells are seen to be arranged circularly. They are a little more "open" in appearance than in the rest of the myocardium. Magnification, $\times 90$.

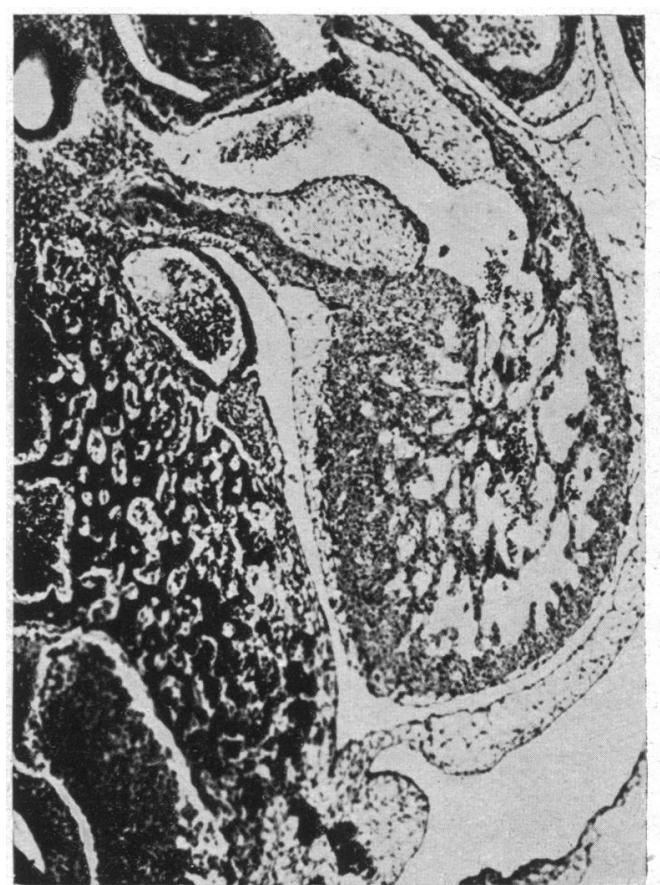

Fig. 2.-Longitudinal section through heart of 7.5-mm. embryo in the line of A-V the canal. The cells along the under surface of the dorsal endocardial cushion stain less deeply than the general myocardium. Note the close relation of this primitive bundle to the under surface of the cushion. Magnification, $\times 50$.

which differentiation makes its appearance along the upper margin of the septum inferius suggests that relative fixity is an important conditioning factor. Thus, the characteristic open appearance of the cells is marked precisely where the upper margin of the septum abuts against the inferior aspect of the endocardial cushion (Fig. 3 and 4). Further forwards, opposite the interventricular foramen, such difference is much less marked. Progressive fusion of the septum inferius with the endocardial cushion leads to forward extension of the bundle. It may be, too, that relative richness in glycogen is associated with lesser activity. As the bundle anlage is traced posteriorly it passes behind the dorsal endocardial cushion intervening between it and the circularly disposed fibres of the A-V ostium. No signs of an A-V node are yet discernible.

At the 7.8-mm. stage there is a tendency for the spongy trabeculæ which have made their appearance in the ventricles, to condense in part as two large bundles applied to the sides of the upper 
part of the interventricular septum (Fig. 5), and it is within these trabeculæ that the branches of the bundle differentiate. A similar arrangement of the ventricular trabecular tissue has been noted by Wahlin (1935) and Sanabria (1936) for the bovine and sheep respectively, whilst Walls' (1947) illustration (pl. 4, fig. II) would seem to indicate a similar state of affairs in the human, too. Sanabria found that differentiation did not occur within these trabeculæ until their upper ends were firmly fused with the interventricular septum, and from this he argued that there was "... une induction . . . émanant des éléments du tronc commun. . . ." However, the effect of fixation against the interventricular septum may be the operative factor. At about the 11-mm. stage (about 24-26 days) the interventricular foramen is closed, anchoring securely the upper part of the septum.

12-22-mm. stage. Once closure of the interventricular foramen has taken place and fixation at the upper end of the septum so increased, differentiation of the branches of the bundle proceeds

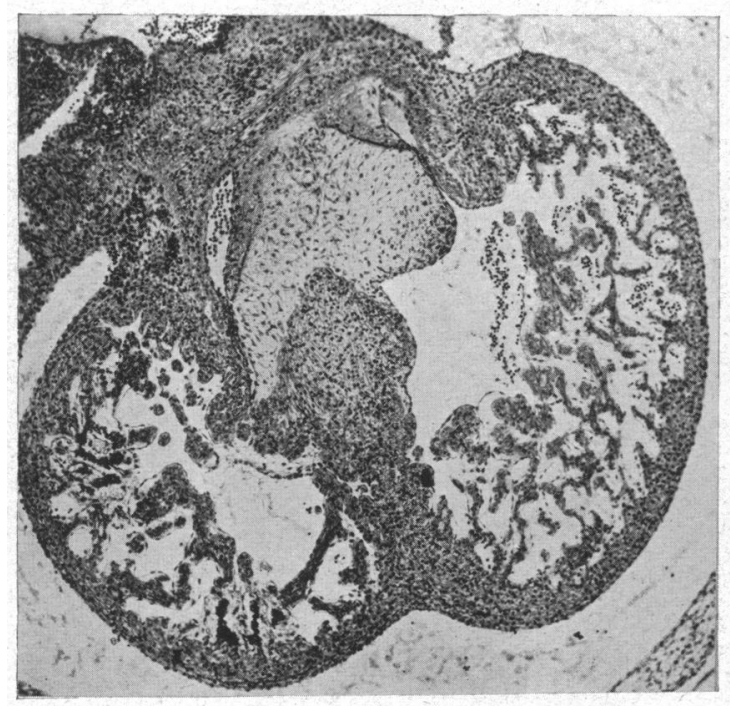

Fig. 3.-Coronal section through $9 \cdot 2-\mathrm{mm}$. heart. The crus commune primordium is seen in the upper part of the interventricular septum abutting on the under surface of the septum intermedium. Note the trabecular meshwork which fills the ventricular cavities in large part. Magnification, $\times 50$.

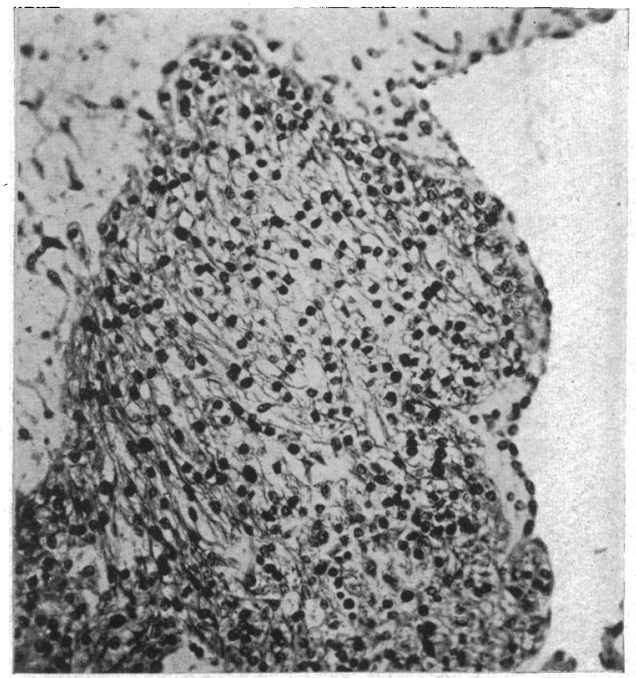

FIG. 4.-High-power view of crus commune shown in Fig. 3. The cells are more vesicular than are those of the general myocardium. Magnification, $\times 170$.

rapidly. Whilst it is difficult to be sure of the exact stage at which interruption of muscular A-V continuity takes place, there seems no doubt that the bundle anlage is defined while such continuity yet exists. The interventricular septum is made up, especially in its upper part, of loosely compressed muscular trabeculæ, each of which is clothed by endocardium. Surmounting the septum the primitive bundle with its branches is draped in the form of an inverted U. Differentiation is more marked in the bundle itself than in its branches, and the bundle, too, is somewhat richer in glycogen than is the general myocardium. Peripherally there is not yet any Purkinje tissue to be made out. The whole bundle is voluminous and ill-defined. The A-V node is inconspicuous and, were it not specially sought, would hardly attract attention. It is the general direction of the cells of the bundle and its branches that catches the eye under the low power of the microscope. When examined under high magnification the differences between specialized and general myocardium are less prominent.

By the 14-mm. stage atrioventricular continuity is largely interrupted. A small accumulation of cells in the inferior part of the interatrial septum is recognizable as the primordium of the A-V 
node. Interposition of undifferentiated connective tissue between atria and ventricles is particularly well seen at the top of the interventricular septum where it is associated with the fibrous basis of the septal parts of the mitral and tricuspid valves. The lconnective tissue core of the mitral septal cusp extends well into the interventricular septum so that the bundle is displaced to the right and appears to circumvent the right side of the septal A-V connective tissue partition. The bundle so displaced may be reduced to a very thin structure, difficult to follow in serial sections. Continuity between the mass of cells in the foot of the interatrial septum construed as A-V node, and the bundle itself does not, however, seem to be broken.

The inverted $U$ disposition of the branches of the bundle draped over the upper margin of the muscular interventricular septum becomes more obvious as development proceeds (Fig. 6), for the limbs of the $\mathrm{U}$ become drawn out as ventricular expansion goes on. Over the left face of the septum cells, which do not, however, differ much from those of the rest of the myocardium, are orientated in the line of the left branch of the bundle, whilst on the right side the branch appears to pass into a

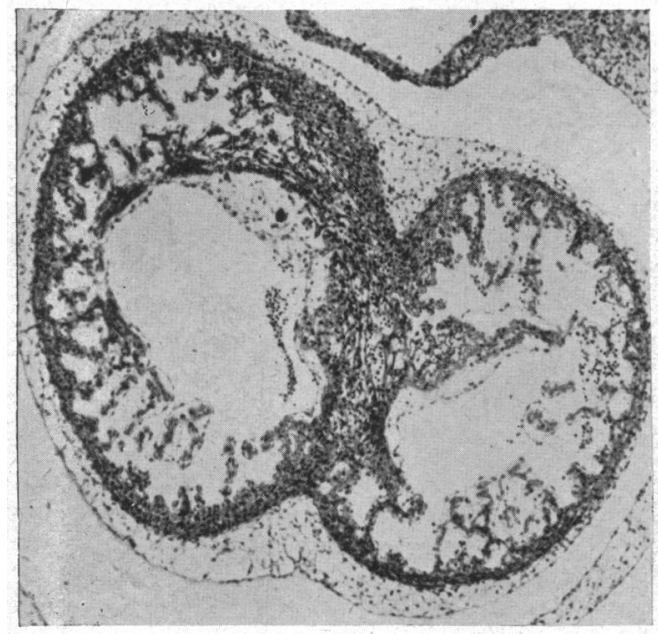

FIG. 5.-Transverse section through 7·8-mm. heart. Some of the ventricular trabeculæ are becoming consolidated against the interventricular septum. Magnification, $\times 50$.

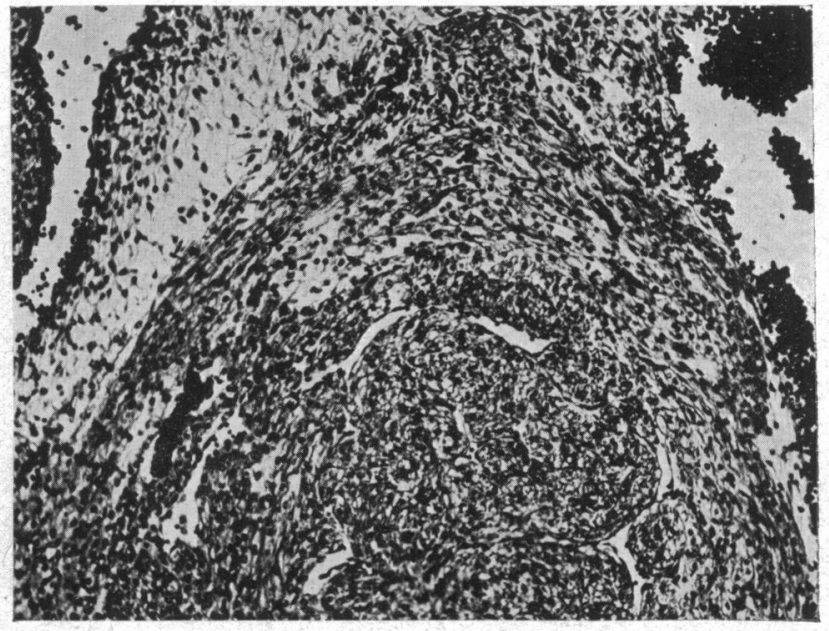

FIG. 6.-Coronal section of the upper part of the interventricular septum in an $18.8-\mathrm{mm}$. heart. Note the primitive bundle branches straddling the septum and passing away on either side of it. The specialized cells are somewhat vesicular. Magnification, $\times 100$.

trabecular mass which is directed through the ventricular cavity towards the apex-the forerunner of the moderator band. The cells of the bundle and its branches are richer in glycogen than are those of the general myocardium (Fig. 13 and 14).

At the 18.5-mm. stage there appear beneath the endocardium of both ventricles islands of clear and somewhat rounded cells with large rather pale staining vesicular nuclei (Fig. 7). These cells are not particularly rich in glycogen at first, and bear little resemblance to Purkinje cells. Gradually they become more numerous until they extend over the distal two-thirds of the ventricular lining.

Three hearts showed a small excess of glycogen in the left ventricle as compared with the right (Fig. 13). Differences in glycogen content of the various heart chambers, met with at later stages, will be described below.

By the 22-mm. stage the A-V node is easily recognizable in the lowest and posterior part of the interatrial septum as a collection of clear cells which have not become orientated in the direction of either right or left atrial fibres. It is still the amassment of cells in this situation, rather than actual structural difference, that catches the eye, though the nuclei are larger and more vesicular than in 
the adjoining atrial walls. One gets the impression that this feature is the result of less dense packing of cells, the node being situated at a null point between fibres passing off into the right and left atria. The displacement of the bundle towards the right noted above becomes accentuated by tilting of the uppermost part of the interventricular septum so that the tricuspid valve comes to be at a somewhat lower level than the mitral (Fig. 8).

The thickness of the ventricular wall is largely made up of muscular trabeculæ. These are in process of consolidation to form a compact mass. The clear subendocardial cells noted above are widespread beneath the endocardium. Sheets of these cells clothing trabeculæ are becoming trapped within the thickness of the ventricular wall. In this way, as becomes apparent in later specimens, an intramural network connected with the subendocardium comes into being. . Because of the nonuniform distribution of the subendocardial cells, not every crypt between trabeculæ is lined by these clear cells. The crypts extend deeply into the heart wall-almost out to the epicardium. At first many have a labyrinthine connection with the ventricular cavity and may contain blood cells. But

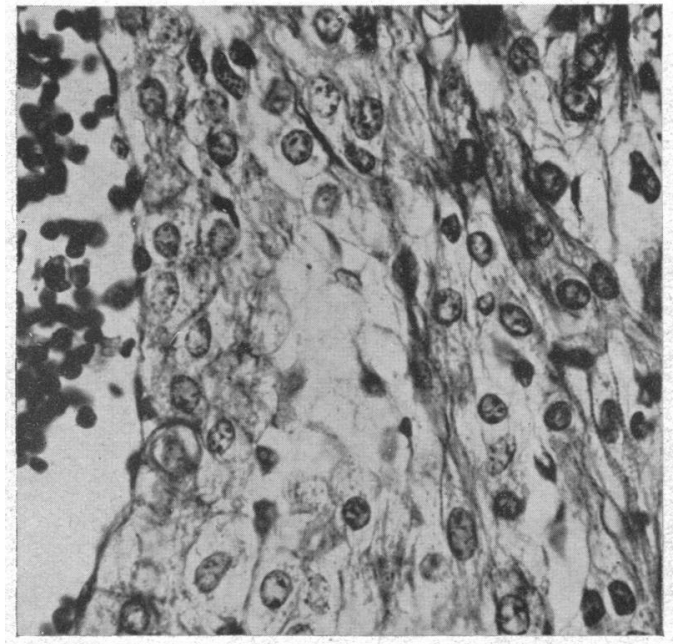

Fig. 7.-Longitudinal section of the left ventricle of 18.5-mm. embryo, showing clear subendocardial cells with pale vesicular nuclei. Magnification, $\times 200$.

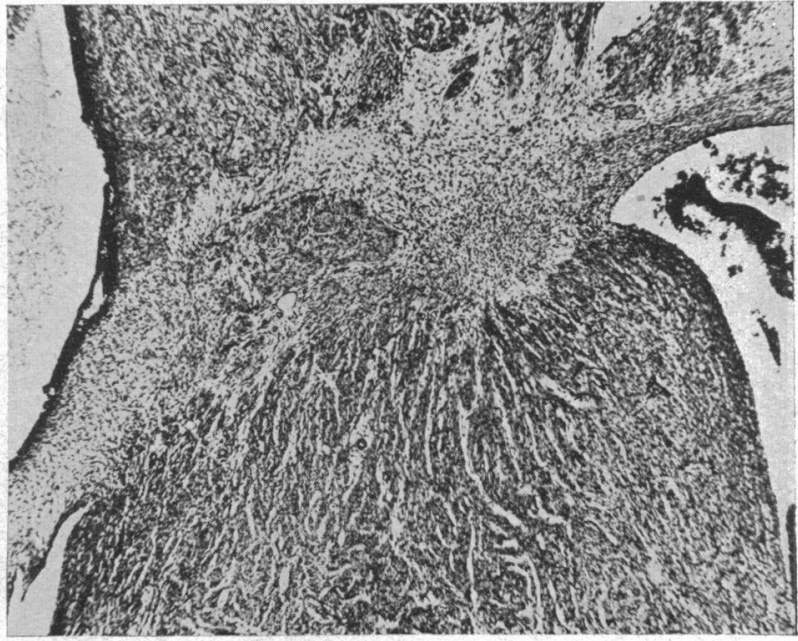

Fig. 8.-Coronal section through 100-mm. heart, showing displacement of the bundle towards the right. Magnification, $\times 80$. Best carmine.

increase of the musculature leads to compression and obliteration of the great majority, whilst incomplete obliteration produces the appearance of small isolated "vessels" in the depths of the myocardium (cf. Fig. 18).

25-100-mm. stage. By the 25-mm. stage the atrioventricular node, the bundle and the right and left branches have all been laid down, while indications of the peripheral elements of the conducting system have emerged. Various milestones in the further evolution of the system remain to be indicated.

Sagittal sections through the $28-\mathrm{mm}$. heart shows the crus commune issuing from the node and passing forward along the top of the interventricular septum. The node is of loose texture, and neither in it nor in the rest of the system is muscle striation present though in the general myocardium it is well developed. Neuroblasts are not yet apparent in association with the node. The atria are richer in glycogen than are the ventricles but the conducting system shows no excess in this particular specimen.

In the 32-mm. specimen nerve fibres were seen for the first time in the upper part of the A-V node, but neuroblasts could not be made out. The node and bundle were again not particularly rich in 
glycogen; the left ventricle was, however, distinctly richer than the right. A well-defined moderator band was present in this specimen, which also showed clearly the displacement of the bundle to the right at the crest of the interventricular septum. The bundle branches became continuous with the large clear cells scattered beneath the endocardium. Here and there strands of these cells dipped into the mouths of intertrabecular clefts. Cell strands were to be found in the upper quarter of the ventricular wall, but they could not be followed into the thickness of the myocardium for any distance. These clear subendocardial cells were often no richer in glycogen than the rest of the myocardium and their vacuolated appearance cannot therefore be referred to glycogen accumulation as is the case in von Gierke's disease. An interesting incidental finding in this specimen was a marked difference in the glycogen content of the two atria (Fig. 15). The boundary between the chambers is remarkably sharp.

At $39 \mathrm{~mm}$., groups of neuroblasts and nerves have made their appearance close to, but not quite within, the atrioventricular node. By $50 \mathrm{~mm}$. they are found actually within the substance of the node (Fig. 10).

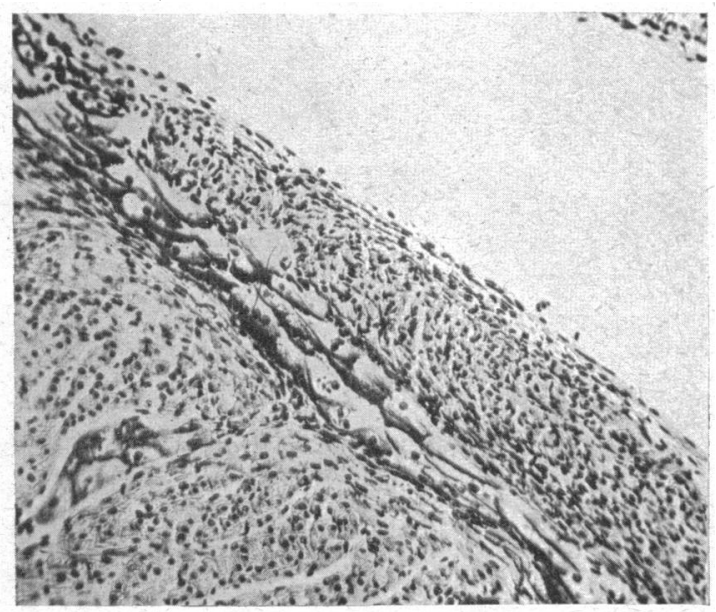

FIG. 9.-Strand of Purkinje cells laden with glycogen. Note the displacement of glycogen to the side of the cells. Interventricular septum of sheep at term. Magnification, $\times 130$. Best carmine.

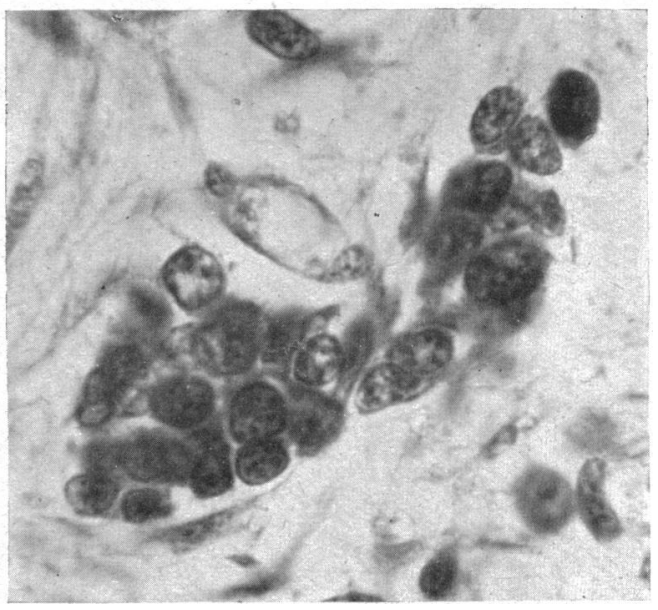

Frg. 10.-Neuroblasts within the atrioventricular node of a $50-\mathrm{mm}$. embryo. Magnification, $\times 1000$.

The value of a glycogen stain for the identification of conducting tissue (Truex and Copenhaver, 1947) is well brought out in the 40- $\mathrm{mm}$. embryo. The somewhat flattened cells lining many of the intertrabecular clefts do not differ conspicuously from ordinary heart muscle cells. When stained for glycogen, however, they are readily differentiated by their high content (Fig. 11). Even at $70 \mathrm{~mm}$. the criterion of glycogen richness is the easiest means of picking out early Purkinje fibres, for there is little advance in histological differentiation (Fig. 12).

At $100 \mathrm{~mm}$. the cellular elements of the bundle branches are beginning to look much more Purkinje-like in character. The right branch in the upper part of the moderate band takes the form of more or less parallel strands of cells packed in connective tissue. Two features that characterize the mature Purkinje cell-perinuclear vacuolation and the occurrence of double nuclei-are beginning to make their appearance, though neither is yet marked. Striated fibrils are present in the marginal part of the cytoplasm, while around the nucleus staining is diffuse and reveals no special structure.

When the right branch is followed in serial sections it may be traced in the moderator band to the parietal wall of the right ventricle. Here it penetrates deeply into the muscle, giving off small 
shoots which gradually fade out as they are traced serially. It is very difficult to say what is their fate but apparently they become continuous with ordinary muscle fibres, though actual transitions such as are common at later stages could not be made out. The A-V node is apparent as an agglomeration of fine anastomosing fibres containing many fibrils which are relatively poorly striated. A similar appearance is presented by the cells of the right and left atrium adjoining the fibrous A-V ring. The microscopic appearance of the A-V node cannot therefore be regarded as specific for that structure. It may be that proximity to a relatively fixed region (the fibrous ring) is the common factor responsible for these resemblances. Numerous ganglion cells and nerves are located all round the A-V ring and in the node itself especially in its posterior part.

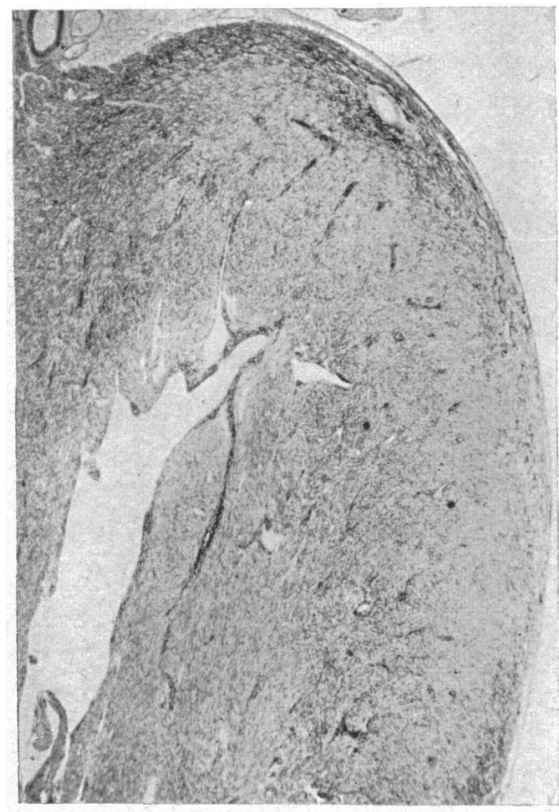

FIG. 11.-Longitudinal section through left ventricle of a $50-\mathrm{mm}$. embryo. Along the line of the intertrabecular clefts strands of glycogen-rich cells have made their appearance. Histologically these cells are not very. different from ordinary heart muscle cells. Bauer stain, without counterstain. Magnification, $\times 35$.

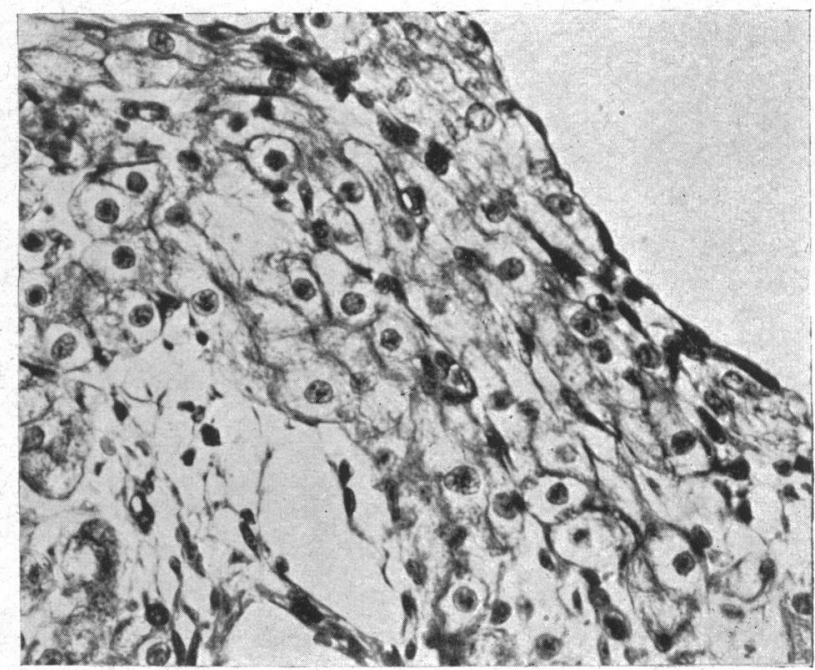

FIG. 12.-Moderator band in a 70-mm. heart. Purkinje cells have not yet made their appearance. Magnification, $\times 510$.

The left branch of the bundle is well developed as a broad thin band under the endocardium of the left face of the interventricular septum. Some of the fibres of the left branch pass into small trabeculæ similar to the moderator band, but most continue down in the interventricular septum. Both branches are relatively richer in glycogen than the general myocardium.

Nerves are present over the surface of both ventricles-particularly richly. on the left, as far down as the distal one-quarter.

145-mm. stage. Histological differentiation of Purkinje tissue within the ventricular walls has progressed so that strands. of bloated cells are readily picked out under the low power. Many of the strands possess no insulating sheath of connective tissue, and in part of their course they may be orientated very differently from the surrounding myocardial fibres (Fig. 18). A perinuclear space is now more marked and binucleate cells common. The peripherally disposed fibrils pass from cell to cell and here and there striation is apparent. Cell boundaries are absent within the Purkinje 


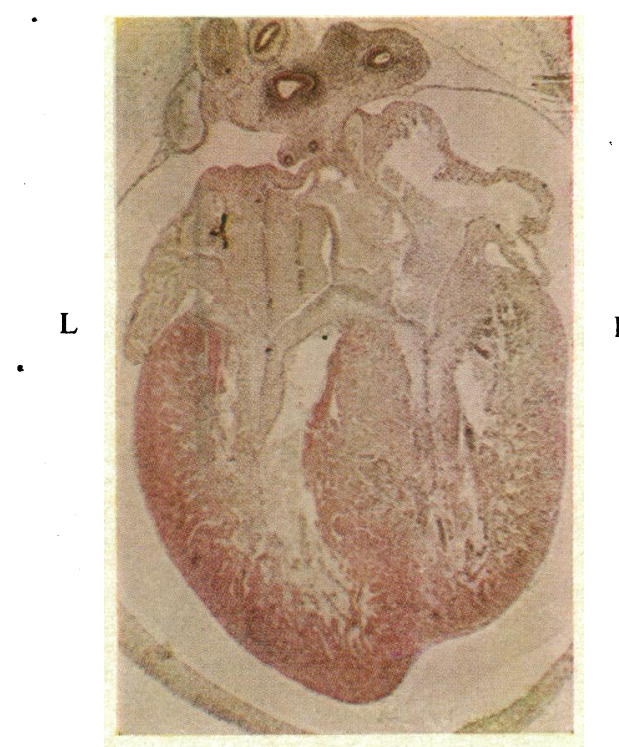

Fig. 13.- Heart of 18.8-mm. embryo, showing relative richness in glycogen of the left branch of the bundle passing down the left face of the interventricular septum. There is a slight excess of glycogen in the left ventricle as compared with the right. Best carmine. Magnification, $\times 18$.

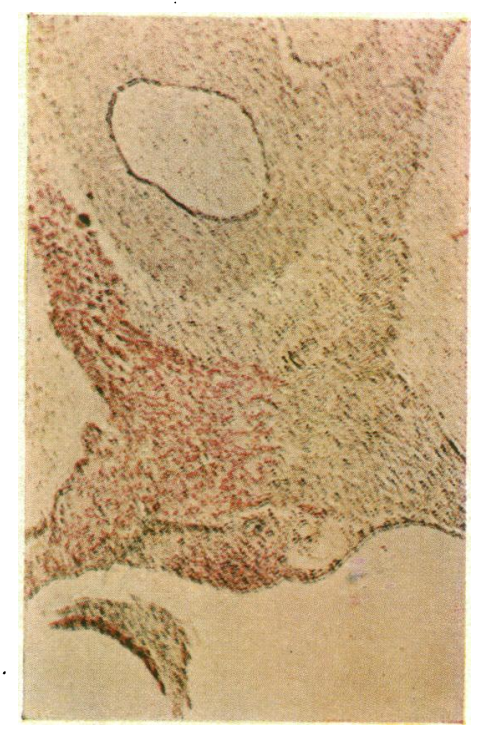

Fig. 15.-Transverse section through the upper part of the interatrial septum in a 32-mm. sheep embryo. In front are the roots of the aorta and pulmonary artery. The right atrium is considerably richer in glycogen than the left. The line of demarcation is remarkably abrupt under high magnification. Magnification, $\times 100$. Best carmine.

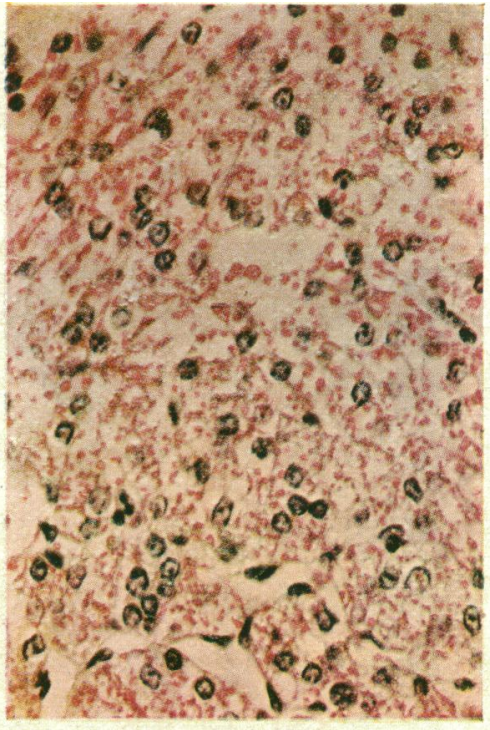

Fig. 14.-High-power view of the top of the interventricular septum (same specimen as Fig. 13) showing more glycogen in the bundle (above) than in the septum (below). Note the trabeculated constitution of the latter. Magnification, $\times 300$. Best Carmine.

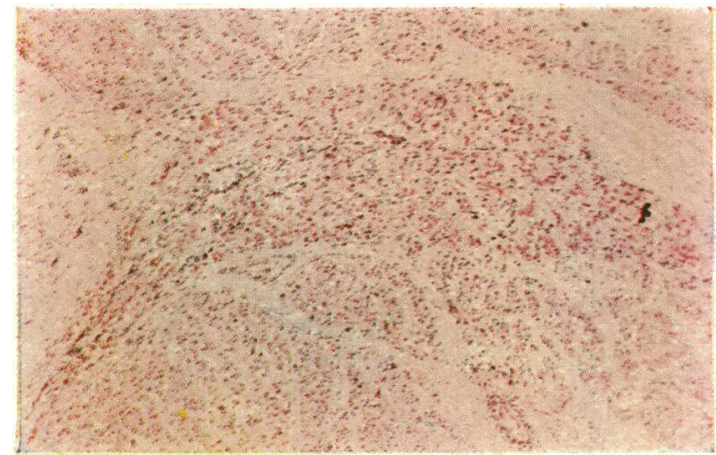

FIG. 16.-Bifurcation of A-V bundle in a 220-mm. embryo. There is considerable glycogen in the specialized tissue. Magnification, $\times 80$. Best carmine.

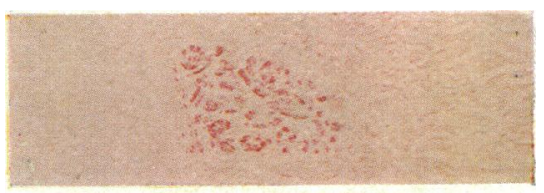

Fig. 17.-A-V bundle emerging from the fibrous $A-V$ partition into the interventricular-septum (to the right of picture). There is rather less glycogen in the crus commune than in the bundle branches. Cf. Fig. 16. Magnification, $\times 80$. Best carmine. 
strands as they are, too; in the ordinary myocardium. Mitotic figures are not to be found within Purkinje cells but appearances very suggestive of amitotic division are common. Not only nerve fibres but ganglion cells, too, are scattered over the ventricular walls (especially on the left side) as far as about half-way down whilst in the interatrial wall nerve cells and fibres are very abundant (Fig. 19). Many masses of cells, such as those illustrated, are scattered about in this region in every section.

250-mm. stage. The branches of the A-V bundle are embedded in a well-defined connective tissue bed, clearly brought out in sections stained by the Masson method, but the connective tissue sheath of the peripheral Purkinje strands does not stain well. The bundle branches (Fig. 16) and the peripheral strands of Purkinje tissue are rich in glycogen. The crus commune may be traced

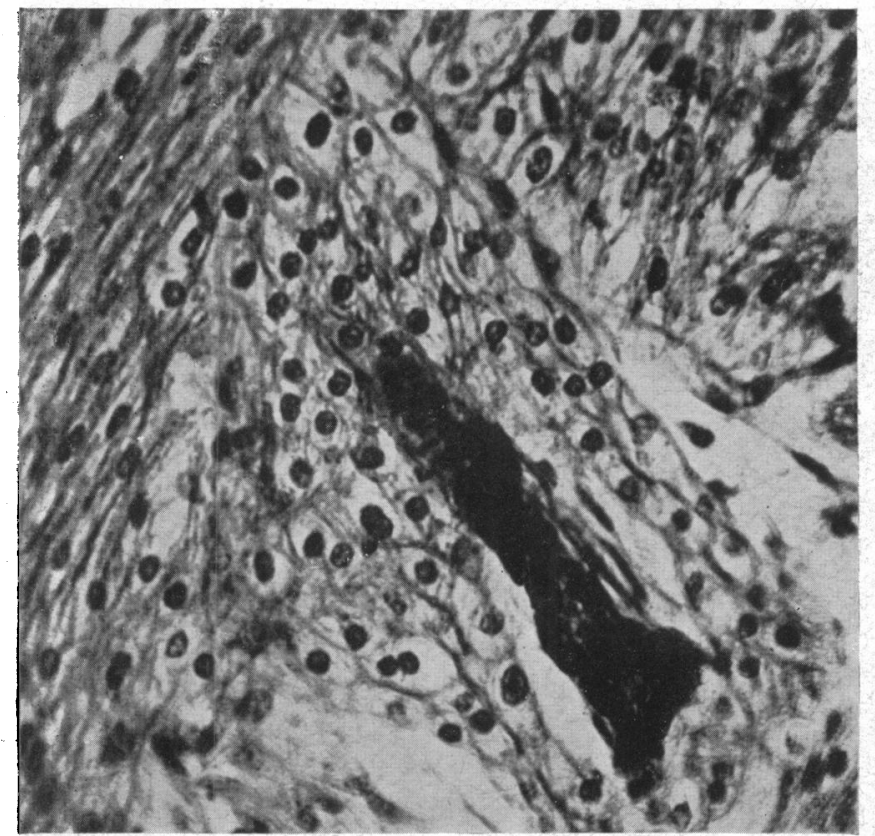

Fig. 18.-Strand of early Purkinje cells in left ventricle of a 145-mm. embryo. The blood vessel accompanying the strand is the remains of an incompletely obliterated intertrabecular crypt. Note the absence of a connective tissue sheath and the difference of direction as compared with the ordinary heart muscle. Magnification, $\times 410$.

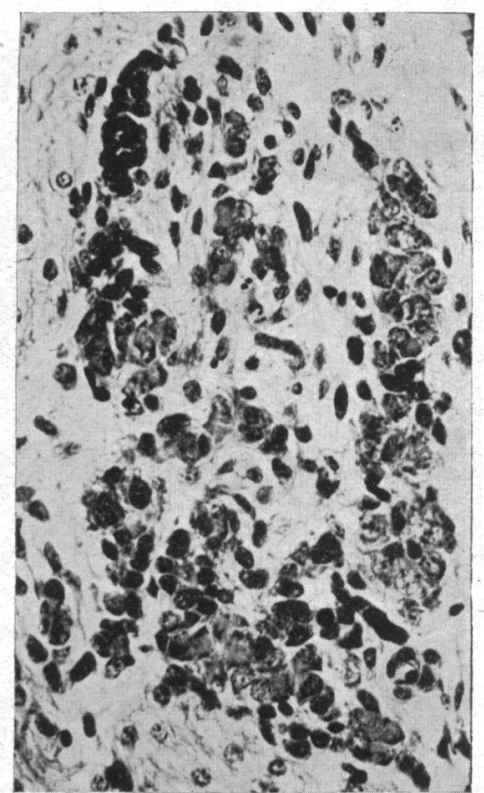

FIG. 19.-Masses of neuroblasts in the interatrial septum of 145-mm. heart. Magnification, $\times 295$.

through the right part of the central cartilage of the heart. The glycogen content becomes less as the bundle is followed proximally and in the A-V node glycogen is no more abundant than in the ordinary atrial musculature (Fig. 17).

An interesting feature was observed in the interventricular septum of this specimen, namely the occurrence of stretch of Purkinje tissue intercalated in the course of an ordinary muscle fasciculus (Fig. 20). It will be referred to further below.

360-mm. stage. Strands of readily recognizable Purkinje tissue permeate the inner two-thirds of the ventricular walls. Many transitions to ordinary heart muscle cells can be seen. The great majority of the Purkinje cells are binucleated. An abundant Purkinje network is present beneath the endocardium, while in the epicardium numerous nerve bundles and occasionally collections of nerve cells are seen. These latter may be found over the upper two-thirds of the ventricles. 
New-born stage. At the time of birth the Purkinje cells have reached their full development (Fig. 22). Strands of specialized cells stand out clearly when stained for glycogen (Fig. 9).

\section{SiNU-ATRIAL NODE}

Sanabria (1936) described in the 7-mm. embryo a rudiment of the sinu-atrial node at the cavoauricular junction. He described it as consisting of fine fibres staining poorly, and having nuclear chromatin arranged in the form of " un long filament pelotonné sur lui même." A careful search both in transversely and in longitudinally sectioned embryos at this stage has revealed only a mass of undifferentiated cells in the region mentioned by Sanabria without the characteristic nuclear
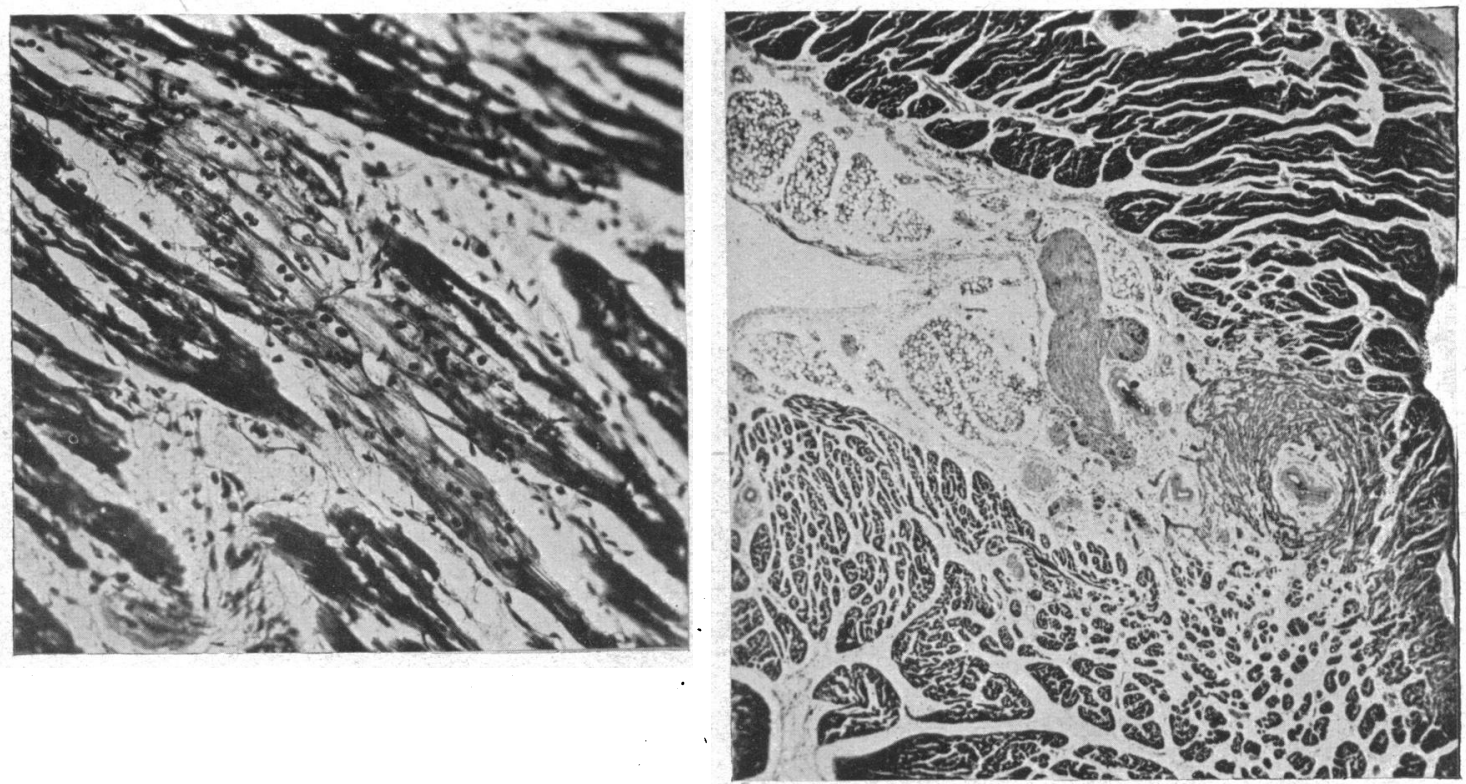

FIG. 20.-Purkinje fibres intercalated in the course of a stretch of ordinary heart muscle fibres. Left ventricle of $220-\mathrm{mm}$. embryo. Magnification,

FIG. 21.-Sinu-atrial node of a $360-\mathrm{mm}$. sheep. The musculature of the node is pale staining and primitive in appearance. It extends from the epicardium to the endocardium. Large nerve trunks and ganglionic masses such as those visible are common, especially on the epicardial aspect of the node. The characteristic artery of the node can be seen. Magnification, $\times 27$.

appearances he describes. Because it is known that the sinu-atrial node will develop in this situation this mass of cells may be looked upon as its forerunner.

At the 22.5-mm. stage there is still no histological specialization of the sinu-atrial node, though the mass of cells within the thick base of the right venous valve is conspicuous and may be taken to be its representative. The right venous valve in this specimen is prolonged to fuse with the lower and posterior part of the interatrial septum and such an arrangement may, perhaps, form the basis for the description given by Retzer (1908) of the origin of the conducting system from the sinus musculature.

Even at $40 \mathrm{~mm}$. little histological differentiation has occurred in this cell mass at the cavo-atrial junction. The cells have retained their clear, somewhat swollen and embryological appearance, whilst round about differentiation has progressed. The rudiment of the small artery that characterized the adult node may be seen here and there in serial sections at this stage. Masses of ganglion 
cells are found on the epicardial aspect of the node. This apparent local lag in development shown by the cells of the node persists and becomes more noticeable so that by the $360-\mathrm{mm}$. stage the node stands out clearly under the low power of the microscope as a pale staining mass of cells grouped round a small artery, and extending from endo- to epi-cardium (Fig. 21). Cross-striation is readily demonstrable with Heidenhain's hæmatoxylin. The same appearances are present in the new-born heart.

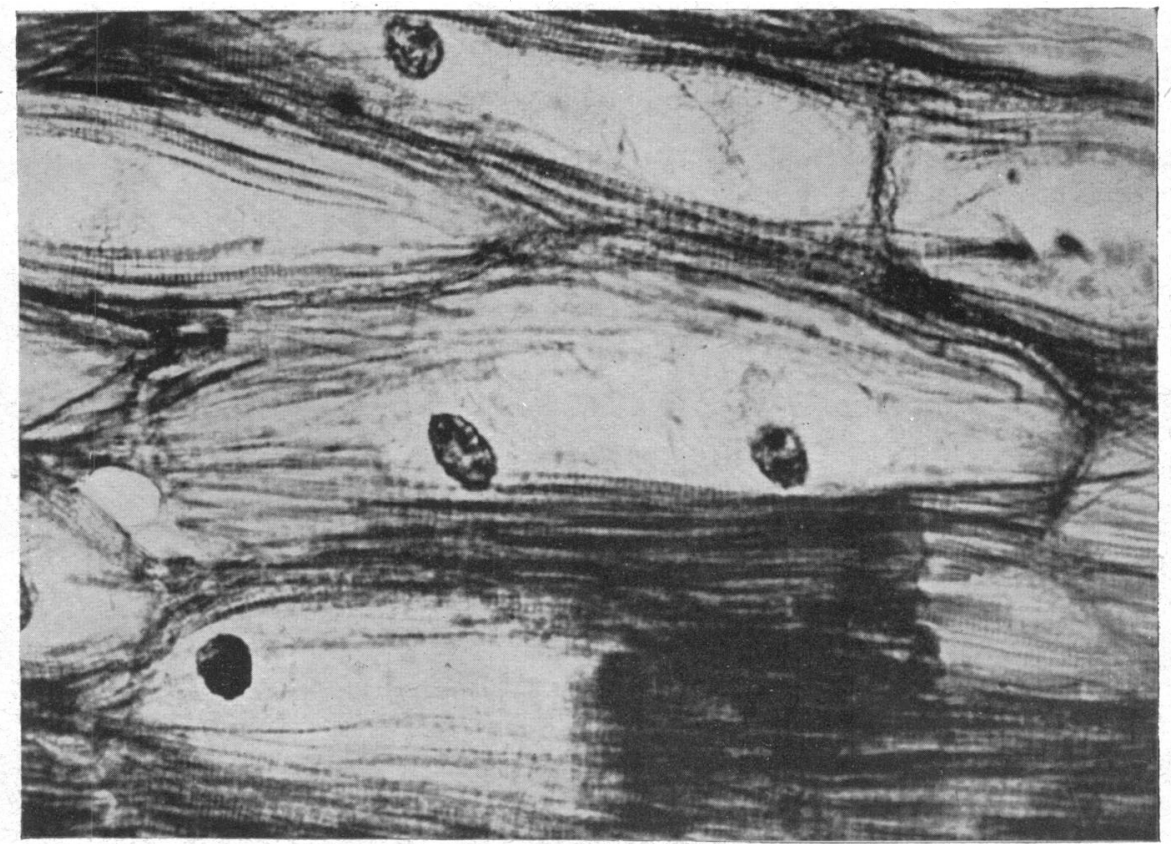

FIG. 22.-Purkinje fibres from the left ventricle of sheep at term. Note the striation in the peripheral part of the "cells" and the appearance of cell boundaries made by intersection of myofibrillæ. Magnification, $\times 880$.

\section{Discussion}

Sinu-atrial node. Structural specialization in the sinu-atrial (S-A) node is generally agreed to occur later than in the other conducting tissues of the heart. Sanabria (1936), however, reported thickening of the auricular myocardium in the sulcus terminalis as early as the 7-mm. stage, and histological differentiation at $10 \mathrm{~mm}$. (sheep). In the present material no distinguishing features could be made out in the cells of the S-A node region until a relatively late stage (about $100 \mathrm{~mm}$.), though, armed with the knowledge that a node will develop in the sulcus terminalis, one may interpret the mass of cells at the base of the right venous valve as its primordium. But this mass of cells-whose raison d'être is apparently to be sought in the form of the valve root-while it may be singled out arbitrarily under the low power of the microscope and dignified with a name, loses all claim to distinction when examined at high magnification. The writer is aware of no high-power photograph demonstrating the early histological differentiation of the node claimed by several authors (Sanabria, 1936; Walls, 1947). What distinguishes the cells is rather the retention of primitive embryonic characters (e.g. poor striation and narrowness) whilst all around atrial cells go on maturing. This poor development is probably to be sought in the special location of these cells in a relatively quiet region, where they are not called upon to undertake energetic contraction. This suggestion finds support in the work of Glomset and Glomset (1940) who, in a review of 
the structure and function of the S-A node in a number of mammals, showed that " the fibers . . . in the bottom and on the sides of the sulcus terminalis become more slender and show less distinctive striations when they are embedded in connective tissue. These alterations disappear when the supporting tissue is of the same amount and type as that found in the surrounding myocardium " (p. 397). Certainly the S-A node makes a clear debut at a time long after the heart has commenced to beat in a mature manner. Histological structure cannot, of course, do more than hint at function, but the microscopic appearances of the node are disappointíng, to say the least, for the great significanee currently attached to it. The significance allotted to the overwhelming nervous tissue in the locality of the node is similarly disappointing (Fig. 26).

The actual origin of the S-A node has long been held to be sinus musculature which persists in the right atrium following the incorporation of the sinus venosus (Keith and Flack, 1906), though the grounds for this belief are by no means clear. Sanabria (1936) points out that once the sinus has been incorporated within the atrium it is impossible to distinguish histologically one from the other. The S-A node develops “ . . . dans une région vraisemblablement sinusale, mais il se différencie aux dépens d'une musculature histolgiquement auriculaire" (p. 24). While it may be true that phylogenetically the node is a derivative of the sinus venosus, such an origin is not apparent in ontogeny.

\section{Atrio-ventricular bundle}

As indicated above, the localization of the early bundle and its branches suggests that it comes into being along lines of relative inactivity of the myocardium. The intramural Purkinje network, which is prominent in the sheep as well as the ox (Abramson and Margolin, 1935-6), may also be formed in the same way between the primitive trabeculæ whose consolidation goes to make up the great mass of the ventricular wall. Thus Fig. 11 shows early accumulation of glycogen in intertrabecular strands of cells in the depths of the myocardium. Incomplete obliteration of parts of these intertrabecular clefts results in small vessel-like clefts and these have no doubt been responsible for the belief in the especially rich blood supply of the conducting system. The interventricular Purkinje strands described by Wahlin (1927) and again by Abramson and Margolin (1935-6) appear to be of the same origin, since the early interventricular septum can be seen to be made up entirely of loosely packed muscle trabeculæ which gradually become consolidated. As expansion occurs on either side of the septum muscle fibres are orientated longitudinally on the two faces of the septum, and these fibres are from the beginning in continuity with the main stem of the bundle developed on the quiet region below and behind the dorsal endocardial cushion. No evidence whatsoever of an active growth of bundle tissue either downwards (Walls, 1947) or upwards (Stienon, 1926) was encountered, and no especially numerous mitotic or amitotic figures are to be found in the early bundle whose nuclei are rather shrunken and stain deeply. Considered from the phylogenetic standpoint the bundle has been looked upon as a remnant of an earlier and much wider A-V continuity. Benninghof (1923) suggests that the system is a part of the Konturfasern which are more clearly seen in lower hearts. From this inner basketwork of fibres which originally contoured the heart tube, Benninghof derives the trabeculæ of the ventricles, the papillary muscles with their chordæ tendineæ and the heart valves as well as the conducting system. He is of the opinion that the importance of the A-V canal as a special segment of the heart tube from which the conducting. bundle is derived, has been exaggerated. He points out that derivation from the canal does nothing to explain the location of the peripheral network, and believes that the main stem of the bundle is a derivative of those Konturfasern which were related to the septum ventriculorum at its appearance in the crocodiles. The present work on the ontogeny of the peripheral network would seem to support derivation from the spongy inner layer of the heart wall (see below).

Some authors maintain that the bundle comes into existence before interruption of the A-V ring takes place (Wahlin, 1935; Shaner, 1929). This precocious appearance has been adduced as evidence of the fundamental significance of the bundle and its importance in the rapidly beating warmblooded mammalian heart (Davies, 1942). However, the poor differentiation of early connective 
tissue makes it difficult to be sure even in complete serial sections at $5 \mu$, that interruption of A-V continuity is complete before the 18-mm., though it does seem to be largely accomplished at about the 14-mm. stage. It would seem then, that (relying on the criteria of orientation and the minimal structural differentiation referred to above) it is possible to identify the bundle before the atria and ventricles become separated by fibrous tissue. Whether this slight anticipation justifies the hypothetical significance accorded it by Davies (1942) is doubtful, especially as the mechanism of relative fixation indicated above would seem to offer a more immediate explanation of the observed. appearances.

The system does not, however, differentiate precociously. Even at relatively later stages the bundle may be such a slender structure and so poorly differentiated that its continuity between atria and ventricles may be difficult to follow.

Whether the bundle be regarded as a remnant or as a neomorphic formation, its cells certainly undergo considerable changes in their histological appearances as further development of the heart proceeds in the sheep. Whether these changes are indeed a specialization (which implies a definite function) or whether they are merely a differentiation (in its strict sense) is a moot point. The changes in structure that take place are such as might result from relative inactivity.

\section{Branches of the $A-V$ Bundle}

Wahlin (1935) and Sanabria (1936) described consolidation of some of the primitive ventricular trabeculæ to form more or less well-defined columns extending from each face of the upper part of the interventricular septum to the lower part of the lateral wall of the corresponding ventricle and the author's findings confirm these observations.

It is within these columns that the right and left branches of the His bundle are developed, the columns themselves becoming more or less applied to the sides of the septum as ventricular growth takes place. On the right side the lower part of this column is not incorporated within the septum but persists as the moderator band (Fig. 23).

\section{The Peripheral Purkinje Network}

The peripheral intramural and subendocardial network arises in situ and is derived from the inner trabeculæ layer of the heart wall. A like conclusion has been reached by Stiénon (1925) Sanabria (1936), and Wahlin (1935). Differentiation is earlier in subendocardial fibres than in the depths of the heart wall. ' There is absolutely no evidence of a progressive peripheral growth of specialized tissue. Phylogenetically, these fibres seem to be related to the Konturfasern of Benninghoff (1923). These fibres are the inner basketwork layer of the heart wall in fishes, amphibians, reptiles, birds, and mammals. Regression of these fibres in higher forms is associated with the development of a well-defined peripheral specialized tissue.

Contrary to what is widely believed, Tawara (1906) was never able to follow microscopically continuity between the branches of the $\mathrm{A}-\mathrm{V}$ bundle and the peripheral Purkinje network. In attempting this in serially sectioned sheep material, he was defeated by the very complicated nature of the terminal ramifications of the right branch (p. 87) and he met with no more success in the case of the left branch. He goes on "Aber was ich unter dem Mikroskop nicht mehr festellen konnte, konnte ich mit blossem Auge ziemlich gut bei anderen Herzen konstatieren " (p. 94). Tawara assumed that the pale subendocardial network to be seen with the naked eye in the sheep ventricles was the terminal ramification of the bundle branches. Mönckeberg (1908) subjected this assumption of Tawara's to direct examination and concluded that the false tendons of the ventricles sometimes contained no muscle tissue at all or only ordinary muscle. In view of this somewhat unsatisfactory basis for so fundamental an anatomical concept as the conducting system, an attempt was made on the larger hearts of the present series to follow the ramifications of the Purkinje network. In FSH $53(100 \mathrm{~mm}$.) a well defined Purkinje bundle in the moderator band was followed 
into the right ventricular wall but the strands of cells quickly dispersed and attempts to link them up were not successful.

The earliest stage at which Purkinje cells may be recognized depends upon the criteria the observer is prepared to accept. Blair and Davies (1935) call attention to the misunderstandings that may arise through loose usage of the term " Purkinje." They stress the view that " continuity with a known part of the conducting system, one or other of the nodes or the A-V bundle or its limbs, is the real criterion of conducting-system fibres, and not peculiarities of histological appearance" (p. 321). Since Tawara, with his vast experience, was unable to adopt this criterion, its use may be regarded merely as a counsel of perfection with little practical importance. It may not, therefore, be out of place to emphasize the essential features of the mature Purkinje cell seen in the new-born lamb heart (Fig. 22).

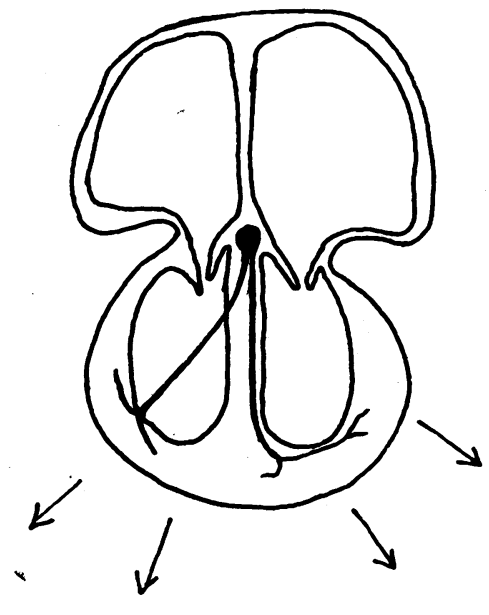

(A)

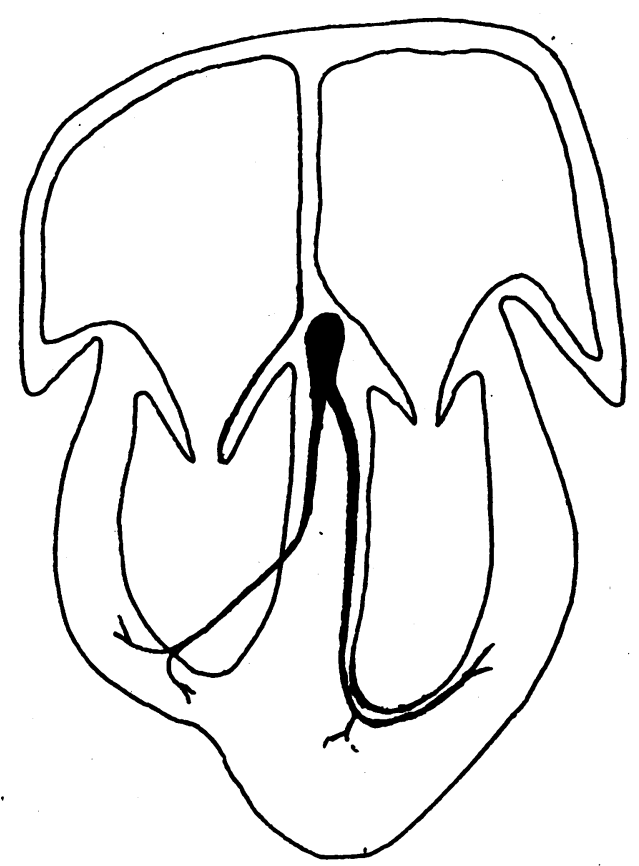

(B)

Fig. 23.-(A) Diagram of the conducting system at an early stage. The right branch of the bundle comes off from the interventricular septum at a high level. (B). Definitive condition. Expansion of the ventricles with elongation has taken place, and as a result the right branch of the bundle comes off much lower down from the interventricular septum. Because of the elongation the bundle is less voluminous in relation to its length than it was originally.

Nucleus. Purkinje himself (1845) described each cell as containing one or two nuclei. Ranvier (1875) gave a similar number, whilst Tawara (1906) said that each cell contained one or two nuclei, rarely three. Abramson and Margolin (1935-6) describe the nuclei as multiple. In the present material the author has never seen a Purkinje cell with more than two nuclei. The great majority appear to have two but occasionally there is only one, though this appearance may be due to the plane of section. The nuclei may be close together or may be separated by a distinct interval. Sometimes the appearances suggest strongly that a process of amitotic division has been accomplished. They are rounded and their chromatin granules a little coarser than in the elongated vesicular nuclei of the general myocardium. Surrounding the nuclei is the well-defined perinuclear clear zone containing a little granular material. Most workers regard this space as artificial (cf. Abramson and Margolin, loc. cit.). Nevertheless, a repulsion field seems to exist around the nuclei, for the deviation of the striated fibrillæ from their neighbourhood is a characteristic appearance. 
Fibrilla. These are situated peripherally, well striated, and pass without interruption from cell to cell over long stretches, and in doing so they may pass from one side of the nucleus to the other (Fig. 22).

Cell boundaries. No intercalated discs or other indication of cell boundaries has been seen in the present material (Bouin and alcohol fixed) and the author would agree with those who are of the opinion that Purkinje tissue is of syncytial nature. (Incidentally intercalated discs were conspicuously absent from the general myocardium in all the material examined.) Where many myofibrillæ cross one another some resemblance to an intercalated disc may result, especially as the Purkinje strand is somewhat constricted at this point (Fig. 22).

Connective tissue sheath. The connective tissue sheath has always been looked upon as an important functional component of the conducting system being supposed to act as a sort of insulating mechanism for the cardiac impulse so that it may be carried without lateral spread (" in geschlossenen Bahnen "-Tawara 1906, p. 187). When histological distinction between the ordinary heart muscle and the specialized tissue is poor, this sheath is the one feature that may enable the observer to follow the bundle branches in serial sections. Ontogenetically the sheath appears late, and quite distinct strands of specialized tissue can be found abutting directly on ordinary heart muscle in late embryos, without an intermediary sheath. At these stages the heart has long been beating in apparently mature fashion. On the other hand the fully developed myocardium contains abundant connective tissue fibres readity demonstrable in a good Masson preparation or by silver impregnation. The connective tissue sheath is merely an excess of this tissue in association with the special fasciculi.

\section{Glycogen Content}

In general the peripheral parts of the conducting system are richer in glycogen than is ordinary heart muscle, and this richness may direct attention to early specialization which might otherwise escape the eye (cf. Truex and Copenhaver, 1947).

Cells that the writer would assess as distinctly of Purkinje type become recognizable round about the 100-mm. stage. Sanabria (1936), too, described them at this stage. At birth they are quite mature. As to the mode of multiplication of Purkinje cells, opinions differ. Sanabria (1936), though he admits the existence of many forms suggestive of an amitotic process (cf. his Fig. X, p. 49), thinks that division is mitotic. Bilobed nuclear formations, which he is satisfied are not artefacts, he attributes to amoboid activity. On the other hand, the writer has nowhere seen a mitotic division in a cell that he would regard as of Purkinje type. Sanabria himself does not say he has seen one either; rather he implies the contrary - " cette absence de mitoses n'implique nullement la possibilité des divisions amitotiques " (p. 48). Nowhere has the writer found an illustration of mitotic division in a Purkinje-type cell. While it is impossible to arrive at a firm conclusion on the basis of fixed preparations alone, cells that are to become Purkinje in character seem to multiply by an amitotic process. The great regularity with which one meets two nuclei in each cell and yet the absence of all trace of a mitotic process, coupled with figures strongly suggestive of simple nuclear fission, make this conclusion probable.

Van der Stricht and Todd (1919) are inclined to the same view, and Retzer (1920) strongly so. The question of proliferation of Purkinje cells is important since they have been held to be the source for wear and tear replacement of the myocardium (Hofmann 1902; Retzer 1920). Retzer concludes that the " . . . sino-ventricular bundle (is) primarily a growth centre for the replacement of cardiac musculature. The cells begin their growth in the sinus region of the heart and by a series of direct nuclear divisions eventually reach the sub-endocardial musculature where they pass into cardiac muscle cells." Van der Stricht and Todd (loc. cit) describe Purkinje cells (in the human) as giving rise to ordinary heart muscle cells by longitudinal fission, and this process they saw clearly in diseased hearts where greater replacement demands had to be met. The idea is an attractive one, and is strengthened by the finding of full-blown Purkinje cells (or forms intermediate between them and ordinary heart muscle cells) in the auricles of birds (Holmes, 1923-4) and throughout the auricles 
and ventricles in the human (Todd, 1932). In many cases these aberrant conducting fibres are far removed from the location of the conducting system. Nevertheless, the existence of these fibres cannot be lightly dismissed (cf. Davies, 1942) and their accurrence must be taken into account in assessing the function of Purkinje fibres as a whole. This important matter has been reviewed for publication elsewhere. However, the localization of the conducting system to the well-defined bundles in the ungulates is difficult to reconcile with the replacement theory of function. Resistance to the idea that Purkinje cells may have any function other than that of conduction of the cardiac impulse (or indeed, no special function at all), springs from the widely-held belief that conduction by the muscle of the A-V bundle has been conclusively demonstrated. The basis of this belief, which is certainly ill-founded, will be examined elsewhere. Some of the relevant ground has already been covered by Glomset and his collaborators (1940-48) who seek to divest the conducting. system of all the properties implied by the name. So far as histological evidence can bear witness as to function, there is nothing about the structure of Purkinje tissue that would lead one to believe in its special conducting powers. On the other hand, the appearance both of the nuclei and of the perinuclear repulsion suggest that an amitotic proliferation may be taking place.

In Fig. 20 a segment of fibres of Purkinje type is shown interposed in the course of a strand of ordinary heart muscle fibres. Ranvier (1875) described similar appearances and Hofmann (1902; Tafel XXVII, Fig. 1 and 2) depicts a like condition. Tawara (loc. cit.) realizing the importance of such an observation from the functional standpoint suggests that Hofmann has committed an error of interpretation and that these appearances are produced by longitudinal section through a rightangled bifurcation of a Purkinje strand. Tawara himself did not encounter such appearances in his own material, and suggests that examination of serial sections might settle the question. 'However, examination of full serial sections in the author's own material allowed of no certain conclusion. Undoubtedly the occurrence of a segment of Purkinje cells intercalated in the course of an ordinary heart muscle strand is uncommon and Tawara's interpretation may well be correct.

\section{The Relation of Purkinje Fibres to Embryonic Cells}

Many eminent histologists have inclined to the opinion that Purkinje cells are embryonic cells of arrested development. Ranvier (1875), Duval (1897), Moriya (1904) among others have all maintained this opinion. A somewhat similar opinion was held by v. Kolliker (1852). He thought the cells were of embryonic character " . . . aber mit Bezug auf die Grösse der Zellen eine eigentümlich entwickelte Form der Muskelfasern des Herzens . . ." (cited by Tawara, 1906). Such an assessment seems altogether reasonable. It does not of course mean that the cells are embryonic but merely that they have been held up in development, have failed to acquire their full complement of striated myofibrils, and have perhaps on this account retained their primitive capacity for multiplication. For Ranvier (1875 “... l'interprétution des fibres de Purkinje ne présente aucune difficulté." for " . . . les fibres de Purkinje sont formées par une série de cellules musculaires arrêtées dans leur developpement; elles représenteraient des fibres cardiaques embryonnaires" (p. 538). Equally eminent workers have, however, maintained an opposing view. Gegenbaur (1877) regarded them as specialized cells, though he shows little ground for this belief. Walls (1947) is the latest of a long line of researchers who have followed this authoritative opinion.

\section{Glycogen Content of the Conducting System}

The fully developed conducting system has long been known to be rich in glycogen (Marchand, 1885; Mönckeberg, 1908; Aschoff and Nagayo, 1908). These older workers relied largely on the iodine staining and on Best's carmine method (1903) for the demonstration of glycogen. Recently developed histochemical methods would indicate, however, that a considerable variation in glycogen content occurs both in the general myocardium and in the conducting system (Yater et al., 1930). and that excess of glycogen does not in itself constitute a distinguishing feature of the Purkinje cell. Indeed, Buadze and Wertheimer (1928) found by direct chemical estimation that in the horse the 
general myocardium contained seven times as much glycogen as the conducting tissue. Truex and Copenhaver (1947) found that Best's carmine staining made positive identification of Purkinje tissue possible in half of their human material. However, these authors observed Purkinje fibres in adjacent sections stained by the azan and Masson methods in cases in which Bests' carmine was entirely negative. The same variability in glycogen-by whatever method adopted for its demonstration-was noted in the present embryonic material, even in specimens of like development and freshness of preservation. Nevertheless, in cases where the general myocardium was relatively rich in glycogen the developing Purkinje tissue stood out well on account of its higher content. The factors that in general influence the demonstrable glycogen, such as the general nutrition of the animal, freshness of specimen, fixative, treatment during dehydration and embedding, would seem to affect equally the content of the general and special myocardium.

Not all parts of the conducting system are equally rich in glycogen. Thus Aschoff and Nagayo (1908), and Mönckeberg (1908) found the A-V node to be free of glycogen. In the present material the glycogen content of the conducting system was found in general to increase from the node distally; the node itself showing little if any excess (cf. Fig. 16 and 17). The final picture of glycogen in the heart can be much modified in intensity by varying the length of differentiation in the methylethyl alcohol mixture. Indeed, more than a perfunctory rinse is often enough to lead to a " glycogenfree" preparation. The intensities of glycogen in Purkinje and ordinary muscle were, however, always parallel. Because of this variability all Best preparations were controlled by the paraperiodate method (modified Bauer) carried out on the next slide of the series under standard conditions.

Differences in the glycogen content of the several heart chambers was an occasional finding. Sometimes (Fig. 15) the difference was marked and abrupt under high power examination. Such differences may perhaps reflect different functional states of the heart chambers at the moment of fixation, and in this connection it is interesting that Marcel and Exchaquet (1938) record an example of auricular double rhythm in the human feetus, the electrocardiographic interpretation being verified by direct observation. Similar differences have been noted in the adult human heart, where the left ventricle may contain more glycogen than the right (Lasch, 1932). Regular variation in glycogen content claimed by Lewis (1925) as between atria, ventricles, and conducting system was not a constant feature in the present material.

The granules of glycogen in both the cells of the general and specified myocardium are often crowded towards one side of the cell. * This appearance is probably a fixation artefact, and the same may be said of the numerous extracellular granules that are to be found in most preparations. These findings reinforce the cautionary note sounded by Danielli (1946) with regard to the misleading picture that may result from diffusion phenomena in histochemical techniques.

The very existence of an A-V bundle in the sheep has recently been roundly denied by Glomset, and Glomset (1940). They describe the A-V node as located in the fibrous A-V plate and without connection with the atrial musculature. Whatever may be the state of affairs in the adult sheep. this description certainly does not hold good for the late fœetus, where it is possible to trace the bundle right through from atria to ventricles. However, in the late fotus the bundle has become so much reduced in size that over long runs of sections one may get the impression that there is no such continuity. But more surprising even than Glomset's denial of the existence of the bundle is the statement (loc. cit. p. 683) "Nowhere did we find any histologic evidence of a change from Purkinje cell to ordinary heart muscle fibre." For such transitions are very common in all older fotal sheep hearts and have been described by many workers, though some (Marceau, 1902; v. Hessling, 1854) have also found blindly ending ramifications of the Purkinje network. The existence of these latter is difficult to establish with certainty even in complete serial sections, and the writer has found no indisputable examples. Their occurrence would be in accord with the mode of development of the conducting system set out in the above account.

In conclusion, the development of the conducting system is not a spectacular or precocious process. Certainly the embryonic heart is able to beat in the mature fashion and give electrical 
recordings comparable in every way with those of the adult long before the special pathway for conduction of the cardiac impulse has been laid down (Marcel and Exchaquet, 1938). Rather the conducting system makes its appearance gradually from cells that by the chance of localization are not concerned with the main work of contraction. These cells do not, naturally, remain quite unchanged whilst all around maturation is proceeding, but, while still retaining obvious embryonic or immature features, develop (in the sheep and other ungulates) well marked charactets of their own.

\section{SUMmARY}

The atrioventricular bundle can be recognized in a sheep embryo of $7.5 \mathrm{~mm}$. length, provided that orientation of cells rather than histological differentiation be accepted as a criterion. The bundle is recognizable before the A-V node. There is no evidence of an active proliferation of cells to produce the conducting system, nor does there appear to be a migration of cells downwards from the node or upwards from the ventricle. All parts of the system are produced by differentiation in situ. The primary location of the A-V bundle along the upper margin of the interventricular septum may be associated with the fact that this region is one of relative rest in cardiac activity. The A-V node arises as a mass of cells that is not caught up in the development of either right or left atrium and therefore retains a somewhat primitive structure. Much the same appearances are shown by cells adjacent to the A-V ring. Neuroblasts appear within the A-V node at about the 50-mm, stage.

The peripheral Purkinje network arises within the ventricular wall along the lines of intertrabecular clefts which become obliterated as consolidation of the myocardium proceeds. Purkinje fibres are first recognizable about the 100-mm. stage.

The origin of the peripheral network is in accordance with a phylogenetic derivation from the Konturfasern of lower forms.

The system is in many cases distinguishable at an early age of development by its high glycogen content. This may be associated with its formation along planes of relative quiescence in the myocardium.

Differences in the glycogen content of the heart chambers may be apparent, and their significance is briefly discussed.

The sinu-atrial node is a relatively late formation, and appears long after the heart has begun to beat in its adult manner.

- Theories of function of the Purkinje network are discussed in the light of histological structure.

I wish to express my gratitude to Professor J. M. Yoffey for his continued interest and encouragement and particularly for making available the technical assistance without which this work would not have been completed. To Professors W. J. Hamilton and J. D. Boyd and the late Sir Joseph Barcroft I am indebted for the loan of valuable material. It is a special pleasure to recall that it was at Professor Hamilton's suggestion that this investigation was undertaken. And, lastly, my thanks are owing to a succession of technical assistants who have helped me in the preparation of so many serial sections. For special mention I would single out Messrs. E.: Park, A. E. Westwood, J. E. Hancock, and K. Hunt.

\section{REFERENCES}

Abramson, D. I., and Margolin, S. (1935-6). J. Anat., Lond., 70, 250.

Aschoff, L., and Nagayo, - (1908). Verh. dtsch. path. Ges. Kiel, 12, 150.

Blair, D. M., and Davies, F. (1935). J. Anat., Lond., 69, 303.

Benninghoff, A. (1923). Verh. anat. Ges., 185.

Best, - (1903). Beitr. path. Anat., 33, 585.

Buadze, S., and Wertheimer, E. (1928). Pflugers Archiv. ges. Physiol., 219, 233.

Calcagno, I. R. (1941a). Rev. Soc. argent. Biol., 17, 213 (read in abstract).

(1941b). Ibid., 17, 221 (read in abstract).

Danielli, J. F. (1946). Nature, 157, 755.

Davies, F. (1942). Brit. Heart J., 4, 66.

Duval, M. (1897). Precis d'Histologie, Paris.

Gegenbaur, C. (1877). Morph. Jahrb., 3, 633. 
Glomset, D. J., and Glomset, A. T. A. (1940). Amer. Heart J., 20, 677. and Birge, R. F. (1945). Ibid., 29, 526. (1948). Archiv. Path., 45, 135.

Hessling, v. T. (1854). Z. wiss. Zool., 5, 189.

Hofmann, H. K. (1902). Ibid., 71, 486.

Holmes, A. H. (1923-4). J. Physiol., 58, Proc. 3.

Keith, A., and Flack, M. W. (1906). Lancet, 2, 359.

Koch, W. (1922). Der funktionelle Bau des menschlichen Herzens. Berlin.

Kolliker, von A. (1852). Handbuch der Gewebelehre. Leipzig.

Lasch, F. (1932). Z. ges. exp. Med., 83, 36.

Mall, F. P. (1912). Amer. J. Anat., 13, 249.

Marceau, F. (1901). C. Rend Soc. Biol., Paris, 53, 653.

Marcel, M. P., and Exchaquet, J. P. (1938). Arch. Mal. Cour. 31, 504.

Marchand, F. (1885). Virchow's Arch. path. Anat. Physiol., 100, 42.

Mönckeberg, J. G. (1908). Untersuchungen über das Atrioventrikularbündel im menschlichen Herzen, Jena.

Moriya, G. (1904). Anat. Anz., 24, 523.

Ohmori, S. (1928). Fukuoka-Ikwadaigaku-Zasshi, 21, 56.

Purkinje, J. E. (1845). Archiv. Anat. Physiol., 12, 281.

Ranvier, L. (1875). Traité Technique d'Histologie, Paris.

Retzer, R. (1908). Bull. Johns Hopkins Hosp., 19, 208. (1920). Contr. Embryol. Carneg. Instn., 9, 143.

Sanabria, T. (1936). Arch. Biol., Paris, 47, 1.

Shaner, R. F. (1929). Anat. Rec., 44, 85.

Skramlik, E. von (1921). Z. ges. exp. Med., 14, 246.

Stiénon, L. (1925). Arch. Biol., Paris, 35, 89.

Tandler, J. (1913). Anatomie des Herzens, Jena.

Tawara, S. (1906). Das Reizleitungssystem des Säugetierherzens. Fischer, Jena.

Todd, T. W. (1932). The Specialized Systems of the Heart; in special Cytology, ed. E. V. Cowdry, New York.

Truex, R. C., and Copenhaver, W. M. (1947). Amer. J. Anat., 80, 173.

Van der Stricht, O., and Todd, T. W. (1919). Johns Hopkins Hosp. Rep., 19, 1.

Wahlin, B. (1935). Das Reizleitungssystem und die Nerven des Säugetierherzens. Inaugural diss, Uppsala.

Walls, E. W. (1947). J. Anat., Lond., 81, 93.

Yater, W. M., Osterberg, A. E., and Hefke, H. W. (1930). Arch. intern. Med., 45, 760. 